\title{
Phloroglucinol Improves Direct Rooting of In Vitro Cultured Apple Rootstocks M9 and M26
}

\author{
Jin-Ho Kim ${ }^{1,2}$, Bo-Min Kwon ${ }^{1}$, Thanh-Tam Ho ${ }^{3,4}$ (i) and So-Young Park ${ }^{1, *(1)}$ \\ 1 Department of Horticultural Science, Division of Animal, Horticulture and Food Sciences, Chungbuk \\ National University, Cheongju 28644, Korea; k_jinh@naver.com (J.-H.K.); qhdksla115@hanmail.net (B.-M.K.) \\ 2 Useful Plant Resources Center, Korea National Arboretum, Pocheon, Gyunggi-do 11186, Korea \\ 3 Institute for Global Health Innovations, Duy Tan University, Da Nang 550000, Vietnam; \\ hothanhtam2@duytan.edu.vn \\ 4 Faculty of Pharmacy, Duy Tan University, Da Nang 550000, Vietnam \\ * Correspondence: soypark7@cbnu.ac.kr; Tel.: +82-43-261-2531
}

Received: 7 May 2020; Accepted: 23 July 2020; Published: 26 July 2020

check for updates

\begin{abstract}
Advances in micropropagation techniques have helped produce true-to-type clones of many horticulturally important plants. However, several cultivars of apple are difficult to root in vitro. In these cases, adventitious roots are induced together with undesirable formation of callus, which decrease the acclimatization rate of in vitro produced plantlets. In this study, two apple rootstocks, M9 and M26, were subjected to different concentrations of indole-3-butyric acid (IBA) to induce root formation. Although addition of IBA to the medium induced root formation, rhizogenesis was accompanied by the undesirable formation of callus in both cultivars. On the other hand, in gene expression analysis, the indole-3-acetic acid (IAA) synthase genes $A A O 1$ and $Y U C 1$ were expressed more highly in M9 than in M26. This suggests that endogenous auxin levels may be higher in M9, which may explain why M9 plantlets are difficult to root and experience high levels of callus formation during propagation. In addition, rooting medium containing $0.1 \mathrm{mg} \cdot \mathrm{L}^{-1}$ IBA was supplemented with different concentrations of phloroglucinol $(0,0.5,1.0$, and $2.0 \mathrm{mM})$ to examine whether direct rooting efficiency in the $\mathrm{M} 9$ could be improved. Addition of $1.0 \mathrm{mM}$ phloroglucinol increased rooting percentage and decreased callus formation in the M9 rootstock. The rootstock M9 is a desirable cultivar but presents a problem with true-to-type direct rooting. Addition of phloroglucinol may improve direct rooting and eliminate callus formation during propagation.
\end{abstract}

Keywords: indole-3-acetaldehyde oxidase (AAO1); indole-3-acetamide hydrolase 1 (AMI1); indole-3-butyric acid (IBA); Malus; phloroglucinol; yucca 1 (YUC1)

\section{Introduction}

Malus domestica is traditionally propagated by budding or grafting scions onto clonal rootstocks raised by stooling or layering [1]. Although apple rootstocks and several well-known cultivars of fruiting apples can be propagated rapidly by in vitro culture, some reports indicate that initiation of tissue culture of apple cultivars presents major difficulties [1], with problems frequently seen in establishing shoot and root induction in vitro. Formation of adventitious roots during clonal proliferation is essential for successful acclimatization of plantlets grown in vitro. Apple (Malus $\times$ Domestica Borkh.; Rosaceae) is an important fruit crop grown mainly in temperate regions of the world. In vitro tissue culture is a biotechnological technique that has been used to genetically improve cultivars (scions) and rootstocks [2]. An updated review presents a range of findings related to tissue culture of apple and other Malus spp. As in other plant species, micropropagation of apple generally includes four stages: establishment of in vitro cultures from ex vitro plants, shoot multiplication, rooting of 
microshoots, and acclimatization [2]. Obtaining high proportions of rooted and established plantlets from Malus cultivars is challenging, and micropropagation research has thus focused on rooting and physiology [1].

Plant growth regulators play fundamental roles in regulating growth and development in response to external stimuli and internal requirements. The phytohormone auxin regulates many aspects of plant growth and development, including apical dominance, tropic responses to light and gravity, root and shoot architecture, vascular differentiation, and shoot elongation [3]. Biosynthesis of indole-3-acetic acid (IAA), a major auxin in plants, occurs via tryptophan-dependent and tryptophan-independent pathways, the molecular details of which are still being determined. Indole-3-butyric acid (IBA) acts as a precursor of IAA in the peroxisomes. Four related indole-3-acetaldehyde oxidase (AAO) genes were recently identified in the Arabidopsis thaliana genome and named AAO1-4 [4,5]. Indole-3-acetamide (IAM) is produced from tryptophan and subsequently converted to IAA by indole-3-acetamide hydrolase 1 (AMI1). Flavin-binding monooxygenase (YUC) functions downstream of tryptophan aminotransferase 1 (TAA1), which catalyzes the conversion of IBA to IAA [6,7]. The IBA pathway is the main pathway for auxin biosynthesis in both monocots and dicots [8].

Apple cultivars differ in terms of their tree structure, time of blooming, growth, development, and fruit maturity [9]. Two commercially popular rootstocks, M9 and M26, were selected for examination of rooting physiology. The M26 cultivar is considered easy to root, with cuttings readily forming roots under greenhouse conditions. By contrast, the M9 cultivar is considered difficult to root, with precise greenhouse conditions required to achieve successful rooting [10]. M9 rootstocks are highly prized by apple growers because they produce dwarf trees with high quality fruit that can be harvested easily and safely. Despite these desirable qualities, the M9 rootstock often presents problems with root development, producing poor, shallow, and fragile roots [11]. In addition, in modern high-density apple planting systems, the M9 rootstock is widely used because of the better light penetration and ventilation inside the canopy of grafted cultivars compared with other rootstocks, which facilitates good flower bud formation, flower development, fruit quality, and root system development [12].

Phloroglucinol, a phenolic compound, is a growth regulator produced via degradation of phloridzin and is a precursor in the biosynthetic pathway of lignin. It promotes plant growth $[2,13,14]$. Phloroglucinol stimulates root development, root elongation, and induction of new roots in papaya [13] and banana [14]. Phloroglucinol was previously reported to improve rooting response in some apple cultivars but to be deleterious or have no effect on other cultivars [15].

To understand the physiology of rooting in apple plantlets, the expression of three IAA synthesis genes, AAO1, AMI1, and YUC1, was analyzed in M9 and M26 rootstocks. Rootstocks were cultured in vitro and subjected to different concentrations of IBA and their growth characteristics examined. IAA synthase genes were highly expressed in M9 plantlets, and phloroglucinol was added to the growth medium during rooting. Phloroglucinol enhanced the rate of true-to-type rooting of the plantlets.

\section{Materials and Methods}

\subsection{In Vitro Rooting}

Apple rootstocks M9 and M26 were grown in vitro, and 1.5-cm long sections with 2-3 leaves were selected. For rooting, MS (Murashige and Skoog, 1962) [16] medium containing 0, 0.1, 0.5, 1.0, or $2.0 \mathrm{mg} \cdot \mathrm{L}^{-1}$ IBA was supplemented with $3 \%(w / v)$ sucrose and $7.4 \mathrm{~g} \cdot \mathrm{L}^{-1}$ agar. The cultures were maintained for 4 weeks at a light intensity of $40-50 \mu \mathrm{mol} \cdot \mathrm{m}^{-2} \cdot \mathrm{s}^{-1}$ photosynthetic photon flux (PPF) at $24 \pm 1{ }^{\circ} \mathrm{C}$ and $20 \%$ humidity.

To investigate the growth characteristics of M9 and M26 rootstocks, plantlets were grown in selected rooting medium, which consisted of MS medium supplemented with $0.5 \mathrm{mg} \cdot \mathrm{L}^{-1}$ IBA, $3 \%(w / v)$ sucrose, and $7.4 \mathrm{~g} \cdot \mathrm{L}^{-1}$ agar. The cultures were maintained for 4 weeks at a light intensity of $40-50 \mu \mathrm{mol} \cdot \mathrm{m}^{-2} \cdot \mathrm{s}^{-1} \mathrm{PPF}$. 
To study the effect of phloroglucinol on direct rooting, 1.5-cm sections of M9 apple rootstocks with 2-3 attached leaves were grown on MS medium supplemented with $0,0.5,1.0$, or $2.0 \mathrm{mg} \cdot \mathrm{L}^{-1}$ phloroglucinol, $0.1 \mathrm{mg} \cdot \mathrm{L}^{-1} \mathrm{IBA}, 3 \%(w / v)$ sucrose, and $7.4 \mathrm{~g} \cdot \mathrm{L}^{-1}$ agar.

Growth parameters including the rooting rate were investigated after 4 weeks of culture. The percentages of rooting and callus formation were calculated based on the number of shoots forming roots/and or callus among total shoots.

\subsection{Gene Expression Analysis}

\subsubsection{Sample Collection and RNA Extraction}

Shoot and root tissue samples were collected from 4-week-old M9 and M26 apple plantlets cultured in rooting medium containing $0.1 \mathrm{mg} \cdot \mathrm{L}^{-1} \mathrm{IBA}$. Total RNA was extracted using a modified acetyl trimethylammonium bromide (CTAB)- $\mathrm{LiCl}$ method as follows [17]. Freeze-dried tissue (1 g) was powdered in liquid nitrogen in a pre-chilled pestle and mortar, then quickly added to $5 \mathrm{~mL}$ prewarmed RNA extraction buffer (diethylepyrocarbonate (DEPC)-treated water containing 2\% CTAB, $2 \%$ polyvinylpyrrolidone (PVP), $100 \mathrm{mM}$ Tris- $\mathrm{HCl} \mathrm{pH} \mathrm{8.0,2.0} \mathrm{M} \mathrm{NaCl,} 25 \mathrm{mM}$ ethyenediaminetetraacetic acid (EDTA), and 2\% 2-mercaptoethanol). The extraction mixture was incubated at $65^{\circ} \mathrm{C}$ for $60 \mathrm{~min}$ with $15 \mathrm{~s}$ vigorous shaking every $5 \mathrm{~min}$. After cooling to room temperature, $5 \mathrm{~mL}$ chloroform/isoamyl alcohol (24:1) was added and mixed by inversion prior to centrifugation at $4500 \mathrm{rpm}$ for $20 \mathrm{~min}$ at $4{ }^{\circ} \mathrm{C}$. The upper aqueous phase was collected and re-extracted with an equal volume of chloroform/isoamyl alcohol (24:1), with mixing and centrifugation as previously. The upper aqueous phase was then transferred to a clean Eppendorf tube, mixed with $1 / 3$ volume of $8 \mathrm{M} \mathrm{LiCl}$, and stored at $4{ }^{\circ} \mathrm{C}$ overnight for RNA precipitation. The mixture was centrifuged at $4500 \mathrm{rpm}$ for $20 \mathrm{~min}$ at $4{ }^{\circ} \mathrm{C}$, and the resulting RNA was cleaned using an RNeasy Plant Mini Kit (Qiagen, Hilden, Germany) according to the manufacturer's instructions. RNA was quantified using a DS-11+ spectrophotometer (Denovix, Inc., Wilmington, DE, USA).

\subsection{2. qRT-PCR}

RNA $(1.0 \mu \mathrm{L})$ was reverse transcribed to cDNA using a ReverTra Ace qPCR RT Kit (Toyobo Co., Ltd., Osaka, Japan) with a reaction volume of $10 \mu \mathrm{L}$. cDNA was subjected to quantitative real-time PCR amplification using SYBR Green premix Taq polymerase (Takara Bio, Shiga, Japan) and gene-specific primers (Table 1). Primers for AAO1, AMI1, and YUC1 were designed using the Primer-BLAST program based on National Center for Biotechnology Information (NCBI) annotations. Amplification was carried out with the following thermal cycle: $95^{\circ} \mathrm{C}$ for $30 \mathrm{~s}$, followed by 40 cycles of $95^{\circ} \mathrm{C}$ for $5 \mathrm{~s}$, $60{ }^{\circ} \mathrm{C}$ for $15 \mathrm{~s}$. Transcript levels were calculated using the standard-curve method and normalized using the actin gene as an internal control. The melting curves of the amplified products were recorded.

Table 1. Primers used for qRT-PCR analysis of AAO1, AMI1, and YUC1 expression.

\begin{tabular}{crc}
\hline Primer & Sequence & Product Size \\
\hline AAO1-F & $5^{\prime}$ - TTCGGCGTTTATGCAGCCTT -3' & \multirow{2}{*}{$110 \mathrm{bp}$} \\
AAO1-R & $5^{\prime}$ - AGAAAAGAAGAGCACGCCGG -3' & \\
AMI1-F & $5^{\prime}$ - CTACAGTTCCAGGGGCTCCA -3' & $120 \mathrm{bp}$ \\
AMI1-R & $5^{\prime}$ - TACTCACCTGGCAGAGTCCG -3' & \\
YUC1-F & $5^{\prime}$ - CCAAAGTTCAACCAGGCCGT -3' & $185 \mathrm{bp}$ \\
YUC1-R & $5^{\prime}$ - CTGGTGTGAAGAACAGGGCC -3' & $166 \mathrm{bp}$ \\
Actin-F & $5^{\prime}$ - CACAGCAAGGGTGAGAAACA -3' & \\
Actin-R & $5^{\prime}$ - TCAAAGTTCACAACCCCACA -3' & \\
\hline
\end{tabular}




\subsection{Statistical Analysis}

All experiments were performed with three replications in independent experiments unless otherwise specified. Significant differences were determined by Duncan's Multiple Range Test (DMRT) $(p<0.05)$ using SAS software (Version 9.4; SAS Institute, North Carolina, NC, USA).

\section{Results}

Apple M9 and M26 rootstocks were cultivated on growth medium containing 0, 0.1, 0.5, 1.0, or $2.0 \mathrm{mg} \cdot \mathrm{L}^{-1} \mathrm{IBA}$, and callus formation and rooting percentages were recorded after 1, 2,3, and 4 weeks cultivation. Shoots produced by both rootstocks responded similarly to the different IBA concentrations, and produced similar fresh weight, shoot length, leaf number, and leaf length values (Table 2). For both rootstocks, rooting occurred most rapidly with $0.1 \mathrm{mg} \cdot \mathrm{L}^{-1}$ IBA and callus development was minimal. Higher IBA concentrations $\left(0.5\right.$ and $\left.2.0 \mathrm{mg} \cdot \mathrm{L}^{-1}\right)$ induced callus formation from the first week in culture and, by week 2, a high percentage of callus formation was observed. Final rooting percentages of both rootstocks were similar with 0.1 and $0.5 \mathrm{mg} \cdot \mathrm{L}^{-1}$ IBA. After 4 weeks, $0.5 \mathrm{mg} \cdot \mathrm{L}^{-1}$ IBA produced $>80 \%$ rooting in the M9 and M26 rootstocks, with increases in rooting percentage observed from week 2 and week 3, respectively (Figure 1).

Table 2. Effects of various concentrations of indole-3-butyric acid (IBA) on growth and rooting of apple rootstocks M9 and M26 after 4 weeks of in vitro culture.

\begin{tabular}{|c|c|c|c|c|c|c|c|c|}
\hline \multirow{3}{*}{ Rootstock } & \multirow{3}{*}{$\begin{array}{c}\text { IBA } \\
\text { Conc. }\end{array}$} & \multirow{3}{*}{$\begin{array}{l}\begin{array}{c}\text { Fresh } \\
\text { Weight }\end{array} \\
\text { (mg/plantlet) }\end{array}$} & \multirow{3}{*}{$\begin{array}{c}\begin{array}{c}\text { Shoot } \\
\text { Length }\end{array} \\
(\mathrm{cm})\end{array}$} & \multicolumn{2}{|c|}{ Leaf } & \multicolumn{3}{|c|}{ Root } \\
\hline & & & & Length & Number & Length & No. of Main Roots & No. of Lateral Roots \\
\hline & & & & $(\mathrm{cm})$ & (ea/plantlet) & $(\mathrm{cm})$ & (per plantlet) & (per plantlet) \\
\hline \multirow[t]{5}{*}{ M9 } & 0.0 & $48.7 \mathrm{~d}^{\mathrm{z}}$ & $2.0 \mathrm{bc}$ & $1.2 \mathrm{~b}$ & $7.0 \mathrm{~b}$ & $0.0 \mathrm{c}$ & $0.0 \mathrm{c}$ & $0.0 \mathrm{~d}$ \\
\hline & 0.1 & $158.5 \mathrm{c}$ & $2.9 \mathrm{a}$ & $1.7 \mathrm{a}$ & $10.1 \mathrm{a}$ & $3.2 \mathrm{a}$ & $2.6 \mathrm{a}$ & $8.2 \mathrm{a}$ \\
\hline & 0.5 & $344.8 \mathrm{a}$ & $2.5 \mathrm{ab}$ & $1.3 \mathrm{~b}$ & $9.4 \mathrm{ab}$ & $0.9 \mathrm{~b}$ & $1.8 \mathrm{~b}$ & $2.6 \mathrm{~b}$ \\
\hline & 1.0 & $364.4 \mathrm{a}$ & $2.3 \mathrm{~b}$ & $1.3 \mathrm{~b}$ & $7.5 \mathrm{~b}$ & $0.7 \mathrm{~b}$ & $1.5 \mathrm{~b}$ & $0.1 \mathrm{c}$ \\
\hline & 2.0 & $237.2 \mathrm{~b}$ & $1.6 \mathrm{c}$ & $0.8 \mathrm{c}$ & $6.6 \mathrm{c}$ & $0.3 \mathrm{~b}$ & $1.8 \mathrm{~b}$ & $0.6 \mathrm{bc}$ \\
\hline \multirow[t]{5}{*}{ M26 } & 0.0 & $54.8 \mathrm{~d}$ & $2.5 \mathrm{a}$ & $1.1 \mathrm{bc}$ & $8.2 \mathrm{a}$ & $0.7 \mathrm{c}$ & $0.1 \mathrm{~d}$ & $0.1 \mathrm{~d}$ \\
\hline & 0.1 & $168.4 \mathrm{c}$ & $2.5 \mathrm{a}$ & $1.5 \mathrm{a}$ & $8.1 \mathrm{a}$ & $2.2 \mathrm{a}$ & $2.4 \mathrm{~b}$ & $2.4 \mathrm{~b}$ \\
\hline & 0.5 & $367.7 \mathrm{a}$ & $2.4 \mathrm{a}$ & $1.3 \mathrm{~b}$ & $8.1 \mathrm{a}$ & $1.5 \mathrm{~b}$ & $3.5 \mathrm{a}$ & $3.5 \mathrm{a}$ \\
\hline & 1.0 & $364.4 \mathrm{a}$ & $2.2 \mathrm{~b}$ & $1.3 \mathrm{~b}$ & $6.6 \mathrm{~b}$ & $0.8 \mathrm{c}$ & $2.3 \mathrm{~b}$ & $2.3 \mathrm{~b}$ \\
\hline & 2.0 & $248.3 \mathrm{~b}$ & $1.5 \mathrm{c}$ & $0.8 \mathrm{c}$ & $5.6 \mathrm{c}$ & $0.3 \mathrm{~d}$ & $1.4 \mathrm{c}$ & $1.4 \mathrm{c}$ \\
\hline
\end{tabular}

${ }^{\mathrm{z}}$ Different letters indicate significant differences $(p<0.05)$ between treatments according to Duncan's multiple range test.

The effect of IBA concentration on the growth of plantlets of both rootstocks was also examined (Table 2). Production of lateral roots was higher in M9 (8.2) than in M26 (2.4) with $0.1 \mathrm{mg} \cdot \mathrm{L}^{-1} \mathrm{IBA}$, but numbers of main roots were similar between the two rootstocks (Figure 1). Similarly, shoots and roots were longer in M9 than in M26 plantlets at $0.1 \mathrm{mg} \cdot \mathrm{L}^{-1} \mathrm{IBA}$. Addition of $0.5 \mathrm{mg} \cdot \mathrm{L}^{-1} \mathrm{IBA}$ induced the production of higher numbers of main and lateral roots per plantlet in the M26 rootstock. For both rootstocks, 0.5 or $1.0 \mathrm{mg} \cdot \mathrm{L}^{-1} \mathrm{IBA}$ increased plantlet fresh weight compared with $0.1 \mathrm{mg} \cdot \mathrm{L}^{-1}$ IBA (Table 2).

The expression patterns of three genes (AAO1, AMI1, and YUC1) involved in auxin synthesis were analyzed in the M9 and M26 apple rootstocks. $A A O 1$ and $Y U C 1$ were expressed at higher levels in M9 shoots than in M26 shoots, but AMI1 expression was comparable between the two rootstocks (Figure 2). Tissue-specific analysis of gene expression in the M9 roots showed that YUC1 expression was higher in roots than in shoots, AAO1 expression was higher in shoots than in roots, and AMI1 expression was similar between the two tissues (Figure 2).

The $0.5 \mathrm{mg} \cdot \mathrm{L}^{-1}$ IBA concentration successfully induced rooting in both rootstocks while also inducing high levels of callus formation (Figure 1). Plantlets that formed callus during rooting produced fewer leaves; however, M9 plantlets without callus exhibited less than $20 \%$ rooting compared to more than $45 \%$ rooting for plantlets with callus (Figure 3). Similar levels of rooting were observed for the 
M26 rootstock (data not shown). Overall, the two M9 and M26 rootstocks exhibited similar rooting and callus formation responses to IBA.
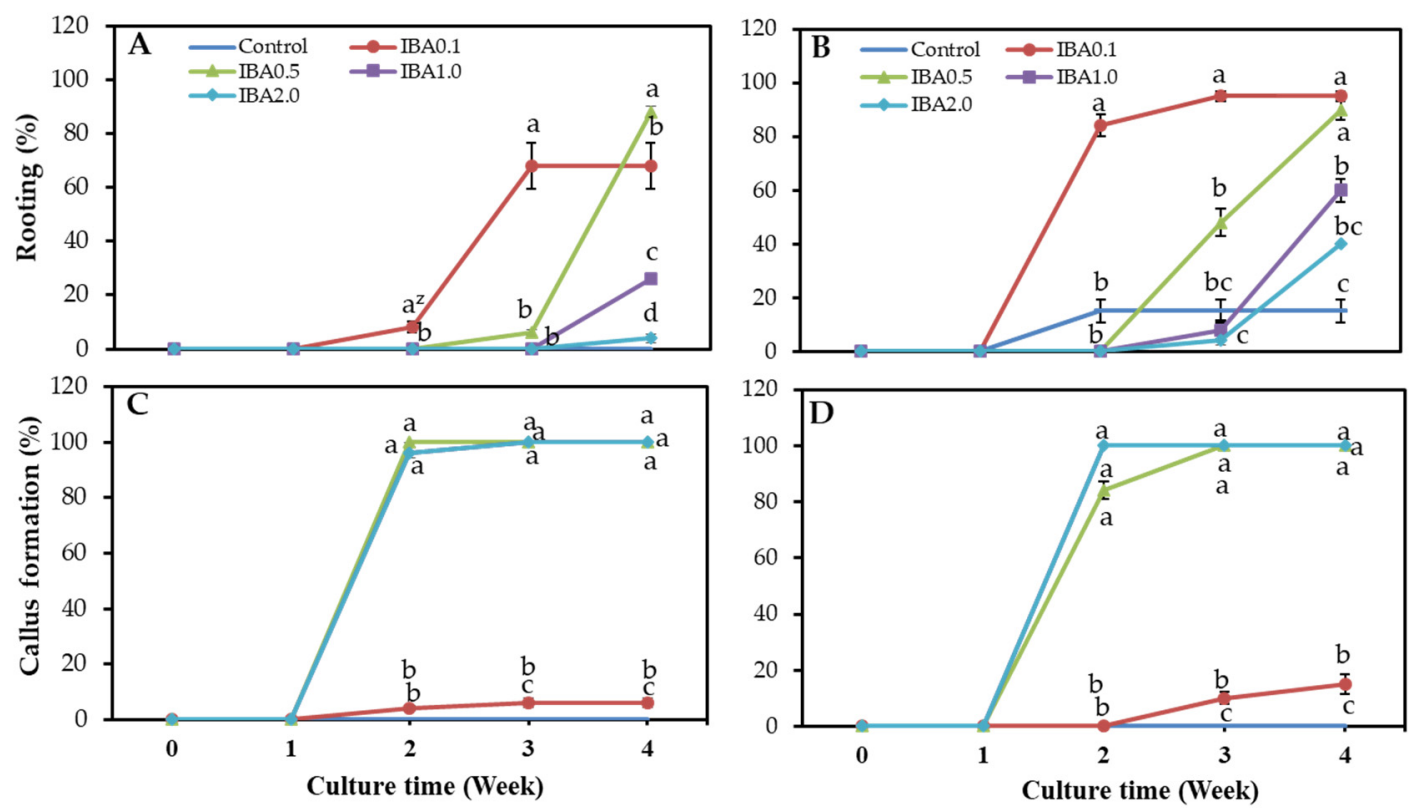

Figure 1. Rates of rooting and callus formation in the apple rootstocks M9 (A,C) and M26 (B,D) on Murashige and Skoog (MS) medium containing $0,0.5,1.0$, or $2.0 \mathrm{mg} \cdot \mathrm{L}^{-1}$ IBA. ${ }^{\mathrm{z}}$ Different letters indicate significant differences $(p<0.05)$ between treatments at each timepoint according to Duncan's multiple range test.

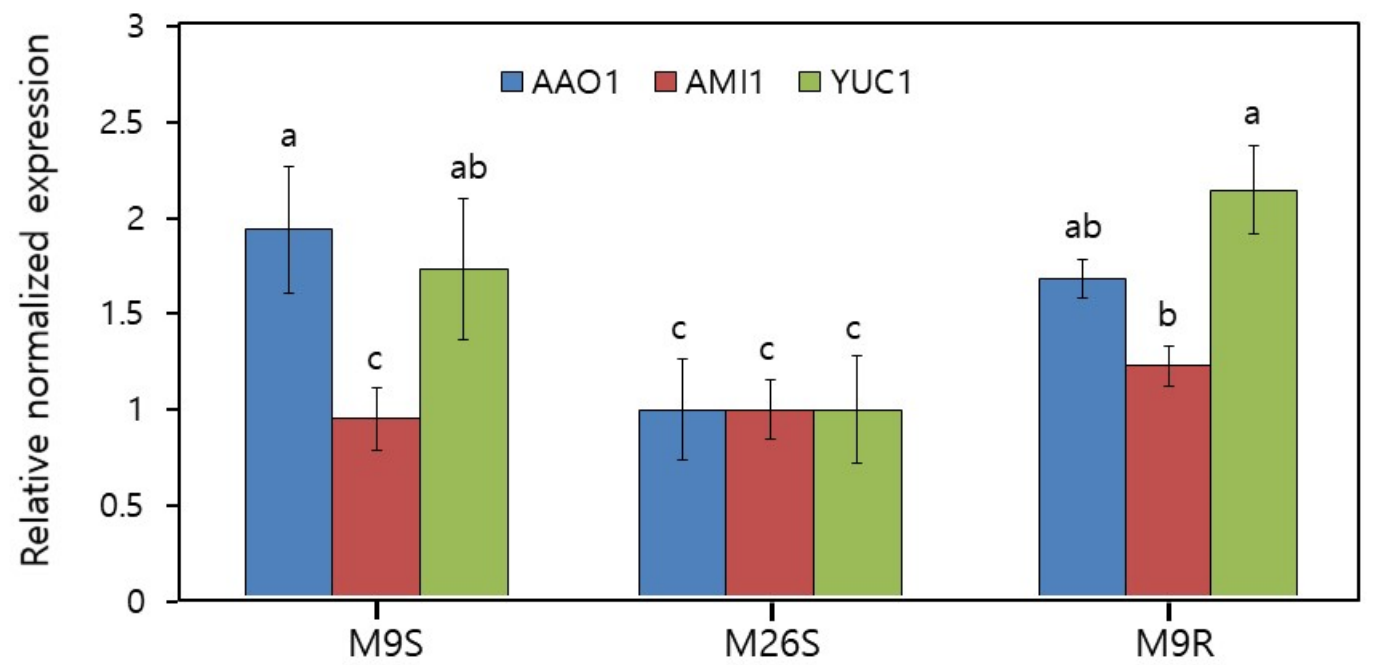

Figure 2. Expression of auxin synthase genes in apple rootstocks M9 and M26 cultured in rooting medium containing IBA $0.1 \mathrm{mg} \cdot \mathrm{L}^{-1}$. Gene expression in M9 shoots (M9S), M26 shoots (M26S), and M9 roots (M9R). Indole-3-acetaldehyde oxidase (AAO1), indole-3-acetamide hydrolase (AMI1), and flavin-binding monooxygenase (YUC1). Expression levels were normalized to actin. Error bars represents standard errors $(n=5)$, and different letters indicate significant differences $(p<0.05)$.

Next, the effect of phloroglucinol $(0.5,1.0$, and $2.0 \mathrm{mM})$ on rooting in the presence of $0.1 \mathrm{mg} \cdot \mathrm{L}^{-1}$ IBA was assessed in the M9 cultivar. Inclusion of a low concentration $(0.5 \mathrm{mM})$ of phloroglucinol in the rooting medium induced early rooting, but a high rooting percentage $(80 \%)$ was observed only from the third week onwards. Addition of a higher phloroglucinol concentration $(1.0 \mathrm{mM})$ induced $100 \%$ rooting by the second week (Figure 4A); however, further increasing the concentration of phloroglucinol 
$(2.0 \mathrm{mM})$ reduced rooting to $80 \%$. Addition of phloroglucinol reduced levels of callus formation. In the absence of phloroglucinol, callus formation reached approximately $30 \%$ by the third week (Figure $4 \mathrm{~B}$ ). Addition of $0.5 \mathrm{mM}$ phloroglucinol reduced the percentage of callus formation associated with rooting to $8.4 \%$; moreover, no callus formation was observed in plantlets grown in medium containing $1.0 \mathrm{mM}$ or $2.0 \mathrm{mM}$ phloroglucinol (Table 3). Maximum root length $(1.87 \mathrm{~cm}$ ) and highest leaf number $(11.1$ per plantlet) were observed in the presence of $1.0 \mathrm{mM}$ phloroglucinol. However, the numbers of leaves and roots were comparable in phloroglucinol-treated and untreated plantlets, while plantlet fresh weight was lower in the presence of phloroglucinol (Table 3). Phloroglucinol treatment dramatically decreased callus formation, and this might explain the lower fresh weight of plantlets.

A
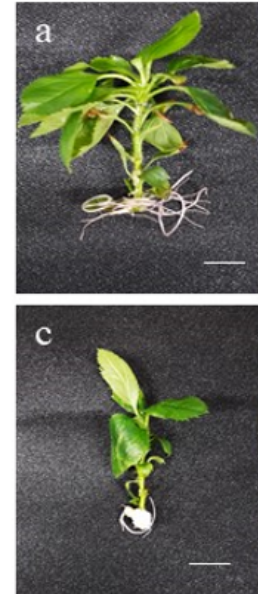

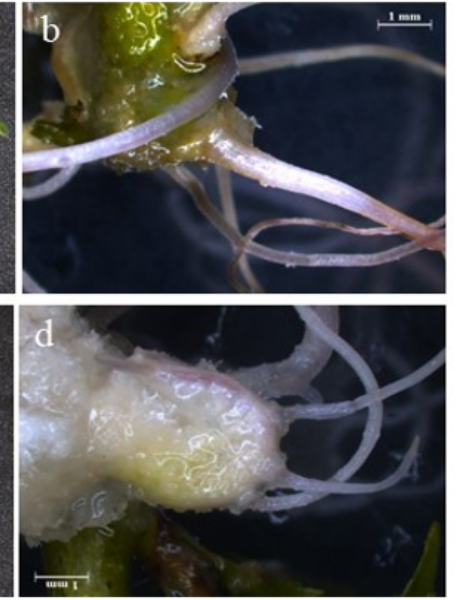

B

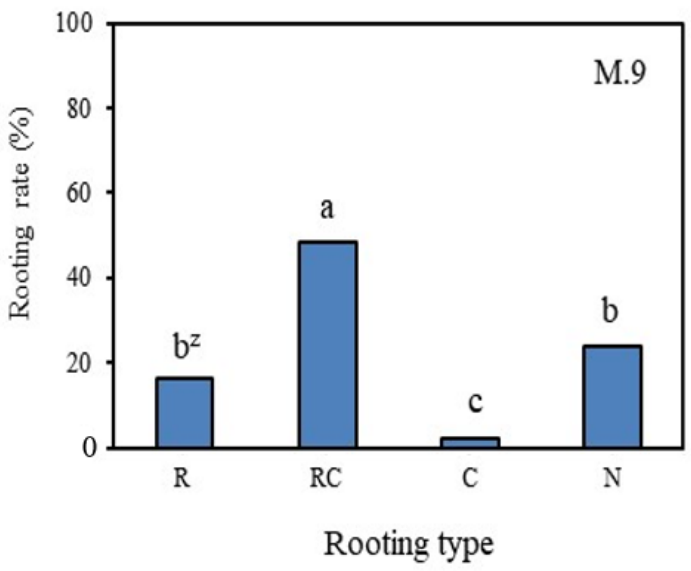

Figure 3. Rooting and callus formation in apple rootstock M9 after 4 weeks of culture on MS medium containing $0.5 \mathrm{mg} \cdot \mathrm{L}^{-1}$ IBA. (A) True-to-type roots $(\mathbf{a}, \mathbf{b})$ and indirect roots induced from callus (c,d). (B) Rooting and callus formation. R: direct rooting without callusing; RC: roots induced from callus; C: callus formation without rooting; N: no formation of callus or roots. ${ }^{\mathrm{z}}$ Different letters indicate significant differences $(p<0.05)$ according to Duncan's multiple range test $(n=3)$. (Scale bar $=1 \mathrm{~cm})$.

A
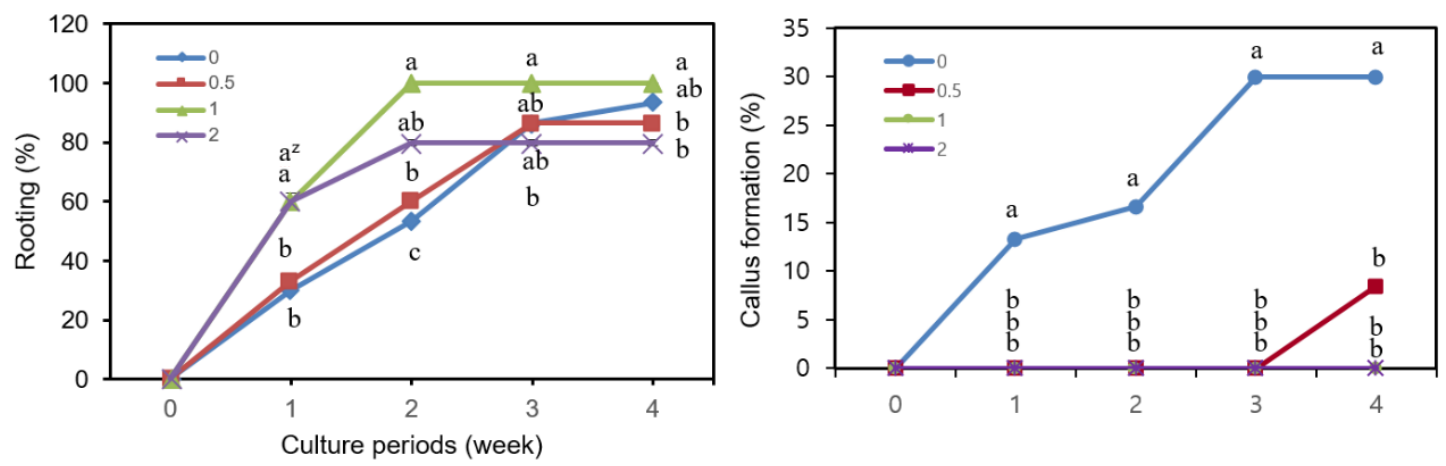

B
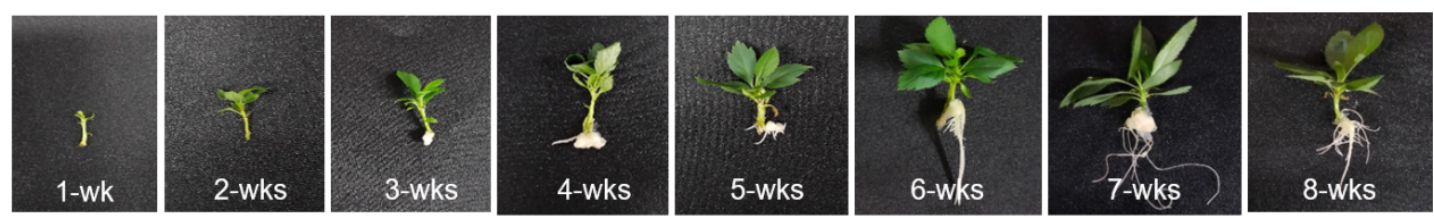

Figure 4. Rooting and callus formation in apple rootstock M9 grown on MS medium containing $0.1 \mathrm{mg} \cdot \mathrm{L}^{-1}$ IBA and different concentrations of phloroglucinol (A). Rooting morphology following growth in rooting medium lacking phloroglucinol for 8 weeks $(\mathbf{B}) .{ }^{\mathrm{z}}$ Different letters indicate significant differences $(p<0.05)$ between treatments at each timepoint according to Duncan's multiple range test. 
Table 3. Effects of various concentrations of phloroglucinol on rooting and callus formation in apple rootstock M9 after 4 weeks of cultivation in rooting medium containing $0.1 \mathrm{mg} \cdot \mathrm{L}^{-1}$ IBA and $0,0.5,1.0$, or $2.0 \mathrm{mM}$ phloroglucinol.

\begin{tabular}{ccccccccc}
\hline Phloroglucinol Conc. & Rooting & $\begin{array}{c}\text { Callus } \\
\text { Formation }\end{array}$ & $\begin{array}{c}\text { Fresh } \\
\text { Weight }\end{array}$ & $\begin{array}{c}\text { Shoot } \\
\text { Length }\end{array}$ & $\begin{array}{c}\text { Leaf } \\
\text { Length }\end{array}$ & No. of Leaves & No. of Roots & $\begin{array}{c}\text { Root } \\
\text { Length }\end{array}$ \\
\hline $\mathbf{( m M )}$ & $\mathbf{( \% )}$ & $\mathbf{( \% )}$ & $\mathbf{( m g / p l a n t l e t )}$ & $\mathbf{( c m )}$ & $\mathbf{( c m )}$ & (per plantlet) & (per plantlet) & $\mathbf{( c m )}$ \\
\hline 0.0 & $93.33 \mathrm{ab}^{\mathrm{z}}$ & $30.00 \mathrm{a}$ & $226.60 \mathrm{a}$ & $2.88 \mathrm{a}$ & $1.54 \mathrm{a}$ & $10.2 \mathrm{a}$ & $5.30 \mathrm{a}$ & $1.94 \mathrm{a}$ \\
1.5 & $86.67 \mathrm{~b}$ & $8.44 \mathrm{~b}$ & $126.58 \mathrm{ab}$ & $2.17 \mathrm{a}$ & $1.63 \mathrm{a}$ & $7.25 \mathrm{~b}$ & $4.06 \mathrm{~b}$ & $1.19 \mathrm{ab}$ \\
2.0 & $100.0 \mathrm{a}$ & $0.00 \mathrm{~b}$ & $168.50 \mathrm{~b}$ & $2.82 \mathrm{a}$ & $1.56 \mathrm{a}$ & $11.10 \mathrm{a}$ & $5.00 \mathrm{a}$ & $1.87 \mathrm{a}$ \\
& $80.00 \mathrm{~b}$ & $0.00 \mathrm{~b}$ & $107.30 \mathrm{c}$ & $2.59 \mathrm{a}$ & $1.17 \mathrm{~b}$ & $10.10 \mathrm{a}$ & $3.70 \mathrm{c}$ & $1.32 \mathrm{~b}$ \\
\hline
\end{tabular}

${ }^{\mathrm{z}}$ Different letters in a column indicate significant differences $(p<0.05)$ according to Duncan's multiple range test.

\section{Discussion}

Auxin is a critical plant growth regulator that is involved in controlling de novo root organogenesis [18-25]. Addition of IBA, an auxin biosynthetic precursor, can be used to induce rooting [18,22,23]. In this study, callus formation was observed in apple M9 and M26 rootstocks when exposed to IBA concentrations as low as $0.1 \mathrm{mg} \cdot \mathrm{L}^{-1}$. Excessive callus formation during rooting can interfere with root formation and impede acclimatization. Previous research showed that short exposure to auxins was needed with rootstocks that exhibited poor rooting in order to reduce callus formation and increase root number [26].

Treatment with exogenous IBA produces a transient increase in endogenous auxin that leads to decreases in peroxidase activity during the inductive phase of rooting, and significant increases in peroxidase activity during the initiation phase of rooting $[27,28]$. Differences in the rooting responses of apple M9 and M26 rootstocks following application of exogenous auxin were previously observed and attributed to differences in endogenous auxin concentration, auxin metabolism, or sensitivity of target cells. Although genetically related, M9 and M26 exhibited differences in free IAA levels in the lower part of shoots in the presence of IBA, indicating that IBA metabolism differed between the two rootstocks. Conjugated IAA levels were significantly higher in M9 than M26, and may have induced a differential response during rooting $[10,29,30]$.

The current study examined the expression of three IAA synthase genes (AAO1, AMI1, and YUC1) to ascertain whether excessive callusing may be stimulated by endogenous auxins. Expression levels of $A A O 1$ and YUC1 were higher in the M9 cultivar than in M26, indicating that difficulties in root formation in M9 may result from high endogenous auxin concentrations. Addition of phloroglucinol to growth medium containing $0.1 \mathrm{mg} \cdot \mathrm{L}^{-1}$ IBA stimulated earlier rooting ( $100 \%$ within 2 weeks) and eliminated callus formation during rooting. In addition, contrary to an earlier study [20], no inhibitory effect of phloroglucinol was observed. Phloroglucinol was previously shown to improve rooting in some apple rootstocks while having either no effect or an inhibitory effect on other rootstocks, and so the role played by phloroglucinol during apple rooting remains unclear. Cultivar specificity of phloroglucinol action has therefore been suggested for this differential response [15].

Addition of IBA to the rooting medium successfully induced rhizogenesis in both the M9 and M26 cultivars of Malus. However, excessive and undesirable callusing occurred early in the cultivation period of both cultivars. Two genes, $A A O 1$ and $Y U C 1$, showed higher expression in the M9 cultivar than in M26. Addition of phloroglucinol to the rooting medium increased rooting efficiency and decreased the time required for rhizogenesis in M9. The addition of phloroglucinol is therefore highly beneficial for induction of rhizogenesis in the highly desirable but difficult-to-root M9 cultivar.

Author Contributions: J.-H.K. contributed to data acquisition and wrote the manuscript. B.-M.K. participated in production of data. T.-T.H. participated in interpretation of data and revising the manuscript for intellectual content. S.-Y.P. made substantial contributions to the conception and design of the study, interpretation of data, and revising the manuscript for intellectual content. All authors have read and approved the published version of the manuscript. 
Funding: This work was funded by the Korea Institute of Planning and Evaluation for Technology in Food, Agriculture, Forestry and Fisheries (IPET) through Agri-Bio Industry, Technology Development Program, funded by the Ministry of Agriculture, Food and Rural Affairs (MAFRA) (grant number 315003-5).

Acknowledgments: Authors were supported by the Brain Korea (BK) 21 Plus Program through the National Research Foundation (NRF) of Korea.

Conflicts of Interest: The authors declare no conflict of interest.

\section{References}

1. Kepenek, K.; Karoglu, Z. The effects of paclobutrazol and daminozide on in vitro micropropagation of some apple (Malus domestica) cultivars and M9 rootstock. Afr. J. Biotechnol. 2011, 10, 4851-4859.

2. da Silva, J.A.T.; Gulyás, A.; Magyar-Tábori, K.; Wang, M.R.; Wang, Q.C.; Dobránski, J. In vitro tissue culture of apple and other Malus species: Recent advances and applications. Planta 2019, 249, 975-1006. [CrossRef] [PubMed]

3. Chandler, J.W. Local auxin production: A small contribution to a big field. Bioessays 2009, 31, 60-70. [CrossRef] [PubMed]

4. Koiwai, H.; Akaba, S.; Seo, M.; Komano, T.; Koshiba, T. Functional expression of two Arabidopsis aldehyde oxidases in the yeast. Pichia Pastor. J. Biochem. 2000, 127, 659-664.

5. Seo, M.; Aoki, H.; Koiwai, H.; Kamiya, Y.; Nambara, E.; Koshiba, T. Comparative studies on the Arabidopsis aldehyde oxidase (AAO) gene family revealed a major role of AAO3 in ABA biosynthesis in seeds. Plant Cell Physiol. 2004, 45, 1694-1703. [CrossRef] [PubMed]

6. Dai, X.; Mashiguchi, K.; Chen, Q.; Kasahara, H.; Kamiya, Y.; Ojha, S.; Dubois, J.; Ballou, D.; Zhao, Y. The biochemical mechanism of auxin biosynthesis by an Arabidopsis YUCCA containing flavin monooxygenase. J. Biol. Chem. 2013, 288, 1448-1457. [CrossRef]

7. Won, C.; Shen, X.; Mashiguchi, K.; Zheng, Z.; Dai, X.; Cheng, Y.; Kasahara, H.; Kamiya, Y.; Chory, J.; Zhao, Y. Conversion of tryptophan to indole-3-acetic acid by TRYPTOPHAN AMINOTRANSFERASES OF ARABIDOPSIS and YUCCAs in Arabidopsis. Proc. Natl. Acad. Sci. USA 2011, 108, 18518-18523. [CrossRef]

8. McSteen, P. Auxin and monocot development. Cold Spring Harb. Perspect. Biol. 2010, 2, a001479. [CrossRef]

9. Bhusal, N.; Han, S.G.; Yoon, T.M. Impact of drought stress on photosynthetic response, leaf water potential, and stem sap flow in two cultivars of bi-leader apple trees (Malus $\times$ domestica Borkh.). Sci. Hortic. 2019, 246, 535-543. [CrossRef]

10. Alvarez, R.; Nissen, S.J.; Sutter, E.G. Relationship between Indole-3-acetic acid levels in apples (Malus pumila mill.) rootstocks cultured in vitro and adventitious root formation in the formation of Indole-3-butyric acid. Plant Physiol. 1989, 89, 439-443. [CrossRef]

11. Akbari, M.; Maejima, T.; Otagaki, S.; Shiratake, K.; Matsumoto, S. Efficient rooting system for apple M9 rootstock using rice seed coat and smoked rice seed coat. Int. J. Agric. 2015, 2015. [CrossRef]

12. Bhusal, N.; Kim, H.S.; Han, S.G.; Yoon, T.M. Photosynthetic traits and plant-water relations of two apple cultivars grown as bi-leader trees under long-term waterlogging conditions. Environ. Exp. Bot. 2020, 176, 104111. [CrossRef]

13. Pérez, L.P.; Montesinos, Y.P.; Olmedo, J.G.; Rodriguez, R.B.; Sánchez, R.R.; Montenegro, O.N.; Escriba, R.C.R.; Daniels, D.; Gómez-Kosky. Effect of phloroglucinol on rooting and in vitro acclimatization of papaya (Carica papaya L. var. Maradol Roja). In Vitro Cell. Dev. Biol. Plant. 2016, 52, 196-203. [CrossRef]

14. Londe, L.C.N.; Vendrame, W.A.; de Oliveira, A.B.; Costa, A.M. Phloroglucinol is effective for in vitro growth and multiplication of banana shoots and roots. Plant Cell Cult. Micropropag. 2017, 13, 34-40.

15. Zimmerman, R.H. Rooting apple cultivars in vitro: Interactions among light, temperature, phloroglucinol and auxin. Plant Cell Tiss. Org. Cult. 1984, 3, 301-311. [CrossRef]

16. Murashige, T.; Skoog, F. A revise medium for rapid growth and bioassay with tobacco tissue culture. Physiol. Plant. 1962, 15, 473-497. [CrossRef]

17. Song, H.W.; Liu, Y.X.; Hu, G.B.; Qin, Y.H.; Lin, S.Q. An improved method for total RNA isolation from recalcitrant lo-quat (Eriobotrya japonica Lindl.) buds. Pak. J. Bot. 2011, 43, 1-9.

18. Greenwood, M.S.; Cui, X.; Xu, F. Response to auxin changes during maturation-related loss of adventitious rooting competence in loblolly pine (Pinus taeda) stem cuttings. Physiol. Plant. 2001, 111, 373-380. [CrossRef] 
19. De Klerk, G.J. Rooting of microcuttings: Theory and practice. In Vitro Cell. Dev. Biol. Plant. 2002, 38, 415-422. [CrossRef]

20. Ahkami, A.H.; Lischewski, S.; Haensch, K.T.; Porfirova, S.; Hofmann, J.; Rolletschek, H.; Melzer, M.; Franken, P.; Hause, B.; Druege, U.; et al. Molecular physiology of adventitious root formation in Petunia hybrida cuttings: Involvement of wound response and primary metabolism. New Phytol. 2009, 181, 613-625. [CrossRef]

21. Gutierrez, L.; Bussell, J.D.; Pacurar, D.I. Phenotypic plasticity of adventitious rooting in Arabidopsis is controlled by complex regulation of AUXIN RESPONSE FACTOR transcripts and microRNA abundance. Plant Cell 2009, 21, 3119-3132. [CrossRef] [PubMed]

22. Correa, L.R.; Troleis, J.; Mastroberti, A.A.; Mariath, J.E.; Fett-Neto, A.G. Distinct modes of adventitious rooting in Arabidopsis thaliana. Plant Biol. 2012, 14, 100-109.

23. Sukumar, P.; Maloney, G.S.; Muday, G.K. Localized induction of the ATP-binding cassette B19 auxin transporter enhances adventitious root formation in Arabidopsis. Plant Physiol. 2013, 162, 1392-1405. [CrossRef]

24. Liu, J.; Sheng, L.; Xu, Y.; Li, J.; Yang, Z.; Huang, H.; Xu, L. WOX11 and 12 are involved in the first-step cell fate transition during de novo root organogenesis in Arabidopsis. Plant Cell 2014, 26, 1081-1093. [CrossRef] [PubMed]

25. Xu, L.; Huang, H. Genetic and epigenetic controls of plant regeneration. Curr. Top. Dev. Biol. 2014, 108, 1-33. [PubMed]

26. James, D.J. Adventitious root formation 'in vitro' in apple rootstocks (Malus pumiia). I. Factors affecting the length of the auxin-sensitive phase in M.9. Physiol. Plant. 1983, 57, 149-153. [CrossRef]

27. Li, S.W.; Xue, L.; Xu, S.; Feng, H.; An, L. IBA induced changes in antioxidant enzymes during adventitious rooting in mung bean seedlings: The role of $\mathrm{H}_{2} \mathrm{O}_{2}$. Environ. Exp. Bot. 2009, 66, 442-450. [CrossRef]

28. Li, H.L.; Zhang, H.; Yu, C.; Ma, L.; Wang, Y.; Zhang, X.Z.; Han, Z.H. Possible roles of auxin and zeatin for initiating the dwarfing effect of M9 used as apple rootstock or interstock. Acta Physiol. Plant. 2012, 34, 235-244. [CrossRef]

29. Mashiguchi, K.; Tanaka, K.; Sakai, T.; Sugawara, S.; Kawaide, H.; Natsume, M.; Hanada, A.; Yaeno, T.; Shirasu, K.; Yao, H.; et al. The main auxin biosynthesis pathway in Arabidopsis. Proc. Natl. Acad. Sci. USA 2011, 108, 18512-18517. [CrossRef]

30. Liang, U.Y.; Fei, W. Anatomical study on rooting process and rapid propagation of apple rootstock M9. J. Northwest. For. Univ. 2013, 28, 106-110. 